\title{
Chromosome Mosaicism in a Child with Features Characteristic of the 'Cat Cry' Syndrome*
}

\author{
J. H. TURNER, L. W. BASS, and S. KAPLAN \\ From the Department of Obstetrics and Gynecology, University of Pittsburgh, School of Medicine and Children's Hospital \\ Pittsburgh, Pa., U.S.A.
}

Lejeune, Lafourcade, Berger, Vialatte, Boeswillwald, Seringe, and Turpin (1963) reported a syndrome which was described as being in consistent association with a deletion in the distal portion of the short arm of a B chromosome (as classified by Patau, 1960). Their report has been followed by descriptions of at least 9 similarly affected individuals. In each instance, karyotypic abnormalities occurring in the B group of chromosomes have been recorded. German, Lejeune, MacIntyre, and deGrouchy (1965), by use of labelling techniques, have evidence demonstrating that the specific chromosome involved is No. 5 .

In addition to the aberrant chromosome picture, a summary of the clinical characteristics of the syndrome would most commonly include: growth retardation, severe mental retardation, hypertelorism, oblique palpebral fissure, epicanthus, low-set ears, abnormal palmar dermatoglyphs, and a unique 'cat-like' cry which has caused the syndrome to be named Maladie $d u$ cri $d u$ chat or 'cat cry syndrome'. Other abnormalities such as dolichosigmoid, cryptorchidism, micrognathia, and strabismus have also been observed but with less consistency.

The purpose of this paper is the presentation of a case having features characteristic of the 'cat cry syndrome', but with an anomalous chromosome pattern that deviates from those observed previously.

\section{Case Report}

Clinical Findings. The propositus was born at term with no complications at labour. The gestational period was uneventful with no history of excess radiation or unusual medication. He was the last in a sibship of three. Previous sibs are alive and apparently normal

Received July 29, 1965.

* This study was supported in part by HRSF Research Grant No. $\mathrm{H}-48$. at this time. The mother's age at the time of birth was 3 I years and the father was 35 years of age. Each io considered to be well within the accepted normaf limits of physical and mental health.

Physical examination at birth revealed a well $\vec{z}$ developed but peculiar looking, light skinned, Negr male. The cry was very high pitched; the sneeze was abnormal, sounding much like a crow; there were repeated hiccups coming in rapid fashion. The babs was tremulous at times. Head, $35 \mathrm{~cm}$; chest, $35 \mathrm{~cm}$. height, 19 in. (48 cm.); weight, 7 lb. $3 \mathrm{oz}$. (3260 g.) The lips were very tight skinned. The eyes were wide set, and grey; bulbs were small; palpebral fissures were narrow and slanted. The hands appeared wide్ There was moderate to severe hypotonia, and a marke bilateral rocker bottom foot deformity. The remaindeo of the examination was normal.

At 9 months of age (Fig. I and 2) his height was 27 in. $(69 \mathrm{~cm}$.$) and the weight was 16 \mathrm{lb} .(7 \cdot 25 \mathrm{~kg}$. $)$ head, $40 \mathrm{~cm}$; chest, $43 \mathrm{~cm}$. Radiographs of skule long bones, and chest were within normal limits. Six teeth were present. He neither sat nor crawled and he held his head up poorly. His mental capacities were considered to be severely retarded. He was spitting up considerably. The cry remained very high pitched and of short duration. All measurements were in lower percentiles at 9 months than they were at birth but the most remarkable change was the head cire cumference which was measured at the 50 percentile at birth and at 9 months of age was less than the thir percentile. He was taking foods and milk well with no: apparent difficulty in swallowing. There have beef no respiratory difficulties.

Dermatoglyphic Analysis. At birth fingerprint and hallucal areas were unreadable because of hypoe plastic ridges. Bilateral simian creases were noted At 9 months, the following information was obtainedF right III interdigital space-loop; left III interdigitå․ space-open field (Table I).

Chromosome Analysis. Chromosome preparation of the child and his parents were made from peripheraP blood samples by the technique described by Turnerg 

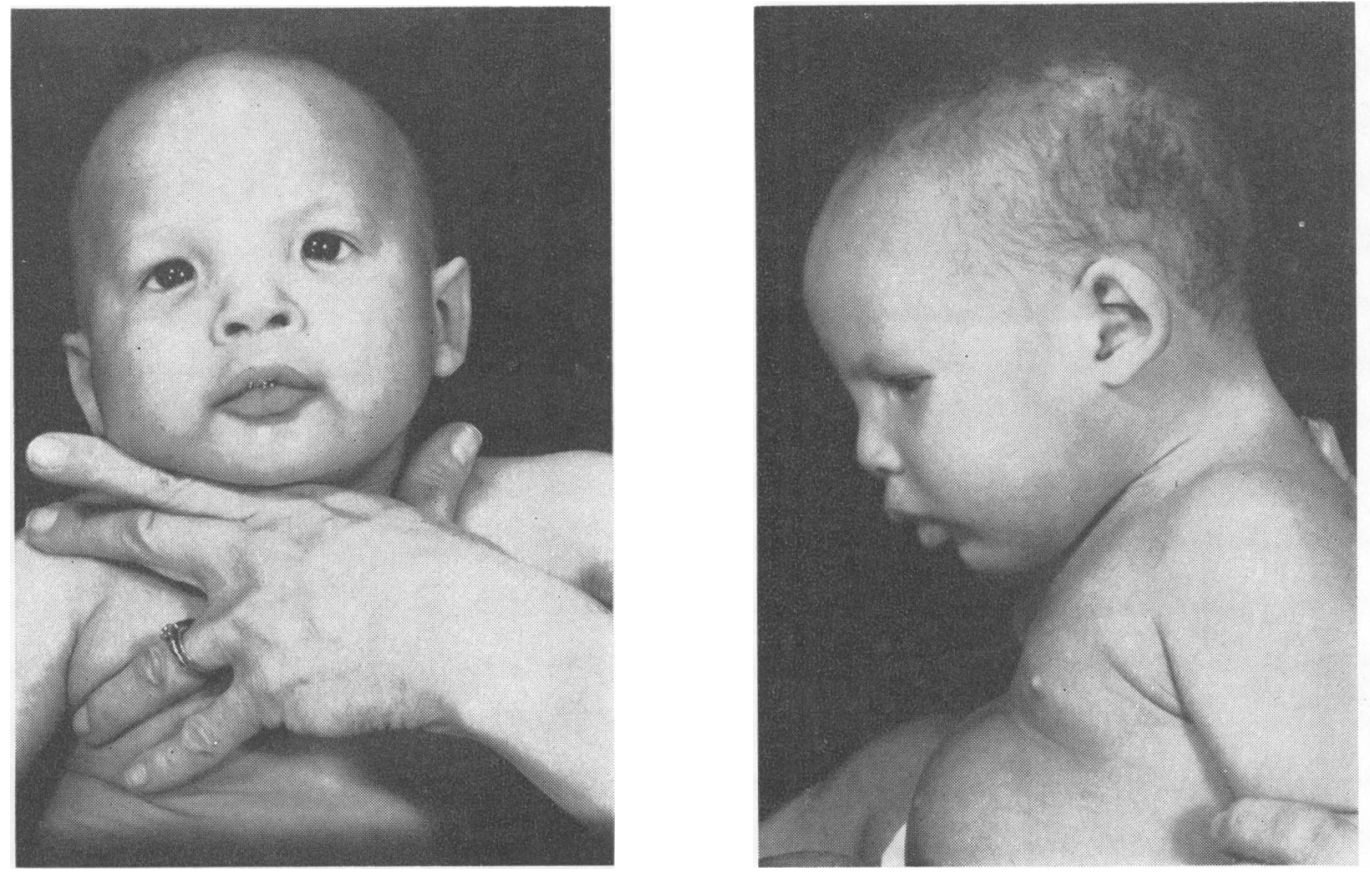

FIG. I and 2. Front and side views of patient at the age of 9 months.

Li, Wald, and Borges (1965). There were no abnormalities of the chromosome complement that could be shown in cells derived from either parent. The karyotypic description of the infant, however, was characterized by three different and consistently appearing cellular types: Type I-a stemline of cells that was normal according to the current standard criteria (London Conference on the Normal Human Karyotype, 1962); Type 2-a stemline of cells having a total count of 46 , but deviating from the expected pattern in that the complement included a non-pairing chromosome (arbitrarily labelled $\mathrm{Bl}$ ), with a relative length comparable to chromosomes commonly classified in group

TABLE I

\begin{tabular}{|c|c|}
\hline atd Angle & Axial Triradius \\
\hline $\begin{array}{l}\text { Right, } 55 \% \\
\text { Left, } 67 \%\end{array}$ & $\begin{array}{l}\text { Right, } t^{\prime} \text { or } 31 \% \text { of palm length } \\
\text { Left, } t^{\prime \prime} \text { or } 45.6 \% \text { of palm length }\end{array}$ \\
\hline Fingerprint Ridge Count & Fingerprints \\
\hline $\left.\begin{array}{l}\text { Right, 4I } \\
\text { Left, 56 }\end{array}\right\}$ Total, 97 & 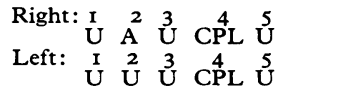 \\
\hline
\end{tabular}

Hallucal Area

Right, whorl

Left, whorl
$A$, and an extra sub-metacentric chromosome (Bs) similar in relative length to chromosome members of group C. The complement included only 2 chromosomes that could be considered as characteristic of the 4 chromosomes standardly classified as group B. Type 3-a stemline of cells characterized by a count of 47. These cells included as part of the complement, $\mathrm{Bl}$ and Bs chromosomes, as described in Type 2 cells above, and an additional fragment with a relative length less than one-half that of the average $G$ group chromosome. The count distribution and the frequencies with which these cell types appeared in the analysis are shown in Table II. A comparative view of chromosomes that distinguish each of the three types is presented in Fig. 3.

\section{Discussion}

The normal chromosome complements observed in the mother and father, and the presence of a few apparently normal karyotypes in the child seem to indicate that the events, resulting in the aberrant karyotypes observed after birth, had occurred in the period immediately following fertilization.

Among the plausible mechanisms that could be offered in explanation of our observations, the most adequate seems to be a sequential chromosome breakage and segment interchange pattern involving 


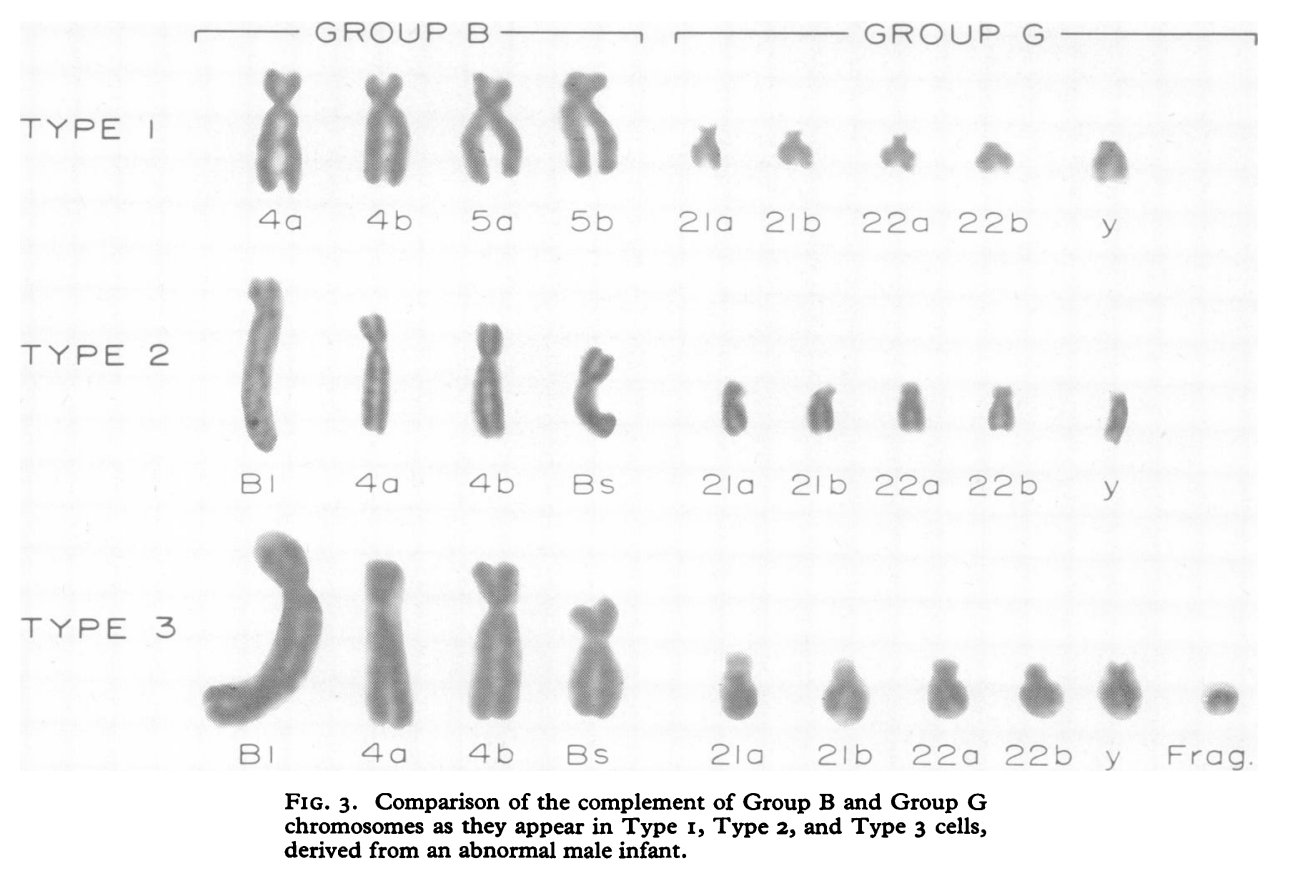

only the B group of chromosomes. For example, two breaks, one occurring in the distal portion of the long arm of one chromosome and the other in the centre portion of the long arm of another, would result in a small acentric fragment and a large centromere-containing element, plus a large

\section{TABLE II}

CHROMOSOME ANALYSIS OF METAPHASE FIGURES DERIVED FROM PERIPHERAL BLOOD CULTURES OF PATIENT AND HIS PARENTS

\begin{tabular}{|c|c|c|c|c|c|c|c|c|}
\hline & \multirow{2}{*}{\multicolumn{5}{|c|}{$\begin{array}{l}\text { Number of } \\
\text { Chromosomes }\end{array}$}} & \multirow{3}{*}{$\begin{array}{c}\text { Total } \\
\text { Cells } \\
\text { Counted }\end{array}$} & \multicolumn{2}{|c|}{ Karyotype Results } \\
\hline & & & & & & & \multirow{2}{*}{$\begin{array}{c}\text { No. of } \\
\text { Cells } \\
\text { Analysed }\end{array}$} & \multirow[b]{2}{*}{ Results } \\
\hline & $<45$ & 45 & 46 & 47 & $>47$ & & & \\
\hline Father & & 2 & 26 & 2 & $\mathbf{I}$ & $3 I$ & 15 & $\begin{array}{l}\text { All cells } \\
\text { Type I* }\end{array}$ \\
\hline Mother & $\mathbf{I}$ & 5 & 50 & 2 & $\mathbf{I}$ & 59 & 15 & $\begin{array}{l}\text { All cells } \\
\text { Type I* }\end{array}$ \\
\hline Patient & I & 2 & 42 & 64 & $\mathbf{I}$ & Iro & 50 & $\begin{array}{l}30 \text { cells } \\
\text { Type } 3 \ddagger \\
\text { 15 cells } \\
\text { Type } 2 \dagger \\
5 \text { cells } \\
\text { Type I* }\end{array}$ \\
\hline
\end{tabular}

* Type I-Cells with count of 46 and normal complement.

$\dagger$ Type 2-Cells with count of 46-B group abnormal in that $\mathrm{Bl}$ and Bs chromosomes are present.

$\ddagger$ Type 3-Cells with count of 47-B group abnormal Bl and Bs chromosome present-and fragment chromosome present. acentric segment and a relatively smaller centric element. Transposition of the large acentrie segment to the long arm of the larger of the centromere-containing elements and failure of the small acentric to attach would result in the fole lowing: (I) a relatively large sub-metacentrie chromosome which, depending upon whether the exchange involved homologous or non-homologous. B group chromosomes, would be either a duplication or a translocation chromosome, (2) a deleted $\overrightarrow{\mathrm{P}}$ group chromosome, and (3) an acentric fragment.

Evidence that the fragment presenting in Type cells is in fact acentric was derived from a subse을 quent study of the propositus nine months after birth. The ratio of the number of Type 2 cells to Type 3 cells had increased from 0.50 to 0.74 , while the over-all frequency of Type I cells remainedE. relatively constant (i.e. $9.5 \%$ of the total cells analysed), indicating that the fragment was perhaps diminishing in frequency because of random migration during mitotic division.

With respect to the three cellular types, it should be pointed out that if the above explanation appliese then two of the three cellular types are balanced in regard to chromatin content and only those of Type 2 are unbalanced, in that a deficiency of chromatin material exists whenever the acentrio fragment was lost. Thus, it seems plausible tha? only Type 2 cells were involved in the develop- $D$ 
mental diversion resulting in the observed phenotypic abnormalities. However, 'position effects' in Type 3 cells, which occur in the highest frequency, might also be causally involved.

The correspondence between the clinical features of this child and some of those described for individuals with the 'cat cry syndrome', the evident involvement of an anomalous group B complement, and the relative mildness of the features, as contrasted with the severe effects described in other B group related abnormalities (Shaw, Cohen, and Hildebrandt, I965), have caused us to think that this child should be considered as an addition to the growing list of 'cat cry syndrome' cases.

\section{Summary}

Mosaicism with three cell lines is described in a child with features characteristic of the 'cat cry syndrome'. The cellular types in order of the frequency with which they present are as follows. Type 3: cells with a count of 47 which includes an abnormally long sub-metacentric chromosome, thought to be either a duplication or translocation B group chromosome, a shorter non-pairing sub-metacentric chromosome thought to be a deleted B group chromosome plus a fragment chromosome less than half the size of an average G group chromosome. Type 2: cells with a count of 46 which are similar in all characteristics to those of Type 3 except that the fragment chromosome is missing. Type $\mathrm{I}$ : cells with 46 chromosomes and a normal karyotype. The possible origin of the cell lines is briefly discussed.

\section{REFERENCES}

German, J., Lejeune, J., MacIntyre, M. N., and deGrouchy, J. (1965). Chromosomal autoradiography in the "cri du chat" syndrome. Cytogenetics, 3, 347.

Lejeune, J., Lafourcade, J., Berger, R., Vialatte, J., Boeswillwald, M., Seringe, P., and Turpin, R. (1963). Trois cas de délétion partielle du bras court d'un chromosome 5. C.R. Acad. Sci. (Paris), 257, 3098.

London Conference on the Normal Human Karyotype (1962). Cytogenetics, $1,325$.

Patau, K. (1960). The identification of individual chromosomes, especially in man. Amer. F. hum. Genet., 12, 250.

Shaw, M. W., Cohen, M. M., and Hildebrandt, H. M. (1965). A familial $4 / 5$ reciprocal translocation resulting in partial trisomy B. ibid., 17, 54 .

Turner, J. H., Li, C. C., Wald, N., and Borges, W. (1965). Preliminary Reports On A Continuing Study of Chromosome Patterns in a General Neonatal Population: Proceedings of a Conference on Research Methodology and Needs in Perinatal Studies, Chapter 6. Charles C. Thomas, Springfield, Illinois. 